\title{
Nematicide Evaluation for the Control of the Nematodes of Yam (Dioscorea rotundata Poir) ${ }^{1}$
}

\author{
J. Román, D. Oramas and J. Green ${ }^{2}$
}

\begin{abstract}
Three field experiments were conducted for the evaluation of non-volatile granular nematicides in yam (Dioscorea rotundata Poir). Nematicides were applied over the furrow at planting or both at planting and post-planting. Aldicarb was more effective controlling nematodes and increasing yields of high quality tubers than carbofuran and fensulfothion. The absence of significant differences between single and split applications of the same nematicide indicates that postplanting treatments are not necessary. The results substantiate the importance of controlling nematodes in yam production.
\end{abstract}

\section{INTRODUCTION}

Yam, Dioscorea spp., is widely planted in Puerto Rico and constitutes one of the most important starchy crops. In spite of the fact that production has not changed during the past decade, farm value has increased significantly. In 1960-61 the farm value of a hundredweight of yam was $\$ 3.64$, whereas in $1979-1980$ the value had increased to $\$ 22.45$ (5).

Farm value, production, and quality of yam are greatly hampered by the attack of soil organisms, particularly nematodes. These attack the roots and the cortical tissue of the edible root stalk producing dry black lesions which affect its quality and thus its commercial value. The first report on the association of nematodes with yams was by Steiner (18). West (19) described the symptoms of the nematosis and named the disease dry-rot of yam. For many years the disease was believed to be caused solely by Scutellonema bradys. Acosta and Ayala (2) reported that, at least in Puerto Rico, another nematode, Pratylenchus coffeae, also produced the disease and caused greater damage because of its widespread distribution throughout the Island. According to these investigators both species produce cracks and dry black lesions in the cortex of the tuber, and in cases of high infection the internal white flesh is greatly deteriorated. The disease is progressive in tubers stored under ambient temperature. Sections of the edible roots are used for food or planting material; the use of planting material with a high proportion of dry rot results in poor stands in the field (12).

The effectiveness of non-volatile nematicides in other root and tuber

${ }^{1}$ Manuscript submitted to Editorial Board February 8, 1983.

${ }^{2}$ Nematologist, Assistant Nematologist, and Assistant Horticulturist, respectively, Agricultural Experiment Station, College of Agricultural Sciences, Mayagëz Campus, University of Puerto Rico, Rio Piedras, P.R. 
crops such as potatoes, sweet potatoes, carrots and sugar beets has been shown by various investigators $(1,8,10,13,14,15,17)$. Limited published research has been directed toward the evaluation of "seed" or tuber treatments of yam $(6,7,12,16)$ and to a combination of tuber and soil treatments $(4,16)$. Other authors have emphasized soil treatments alone $(3,6,9,16)$. This paper presents results of field experiments where various non-volatile or granular nematicides applied to the soil were evaluated for the control of nematodes and yield improvement.

\section{MATERIALS AND METHODS}

Field experiments were established, one each, during the spring of 1979, 1980 and 1981 at the Corozal Agricultural Experiment Substation in an Ultisols soil ( $42.36 \%$ clay, $29.64 \%$ sand, $28.00 \%$ silt, $2.21 \%$ organic matter and $\mathrm{pH}$ 4.58) predominantly infested with $P$. coffeae and Rotylenchulus sp. White yam, $D$. rotundata, tuber pieces of approximately $1 / 2$ lb. and infected with $P$. coffeae were planted at a distance of $0.45 \times 1.5$ $\mathrm{m}$ in experimental plots consisting of 4 rows $4.5 \mathrm{~m}$ long. Nematicides were applied in a $30 \mathrm{~cm}$ wide band over the furrow at planting, and in 1979 applications were also made along each side of the rows 4 months after planting. The application was made by hand from glass jars, whose plastic caps were perforated with 2-mm diameter holes to facilitate even distribution of the material. Three soil samplings were made for nematode determination: before treatment, 6 weeks after treatment and at harvest. In the laboratory, nematodes were isolated from $250 \mathrm{~cm}$ soil samples with the method described by Christie and Perry (11). Number of $P$. coffeae and Rotylenchulus sp. in three samplings of each experiment were averaged and the percent of nematode control calculated. Plants were fertilized 1 month after sprouting with an 8-8-13 analysis at the rate of $1,120 \mathrm{~kg} / \mathrm{ha}$. Ametrine and Gramoxone for weed control and Benlate for foliar fungi were applied as needed. Analyses of variance were conducted after each test. Treatments, including non-treated controls, were as follows: in 1979, carbofuran 5G and 10G, fensulfothion $15 \mathrm{G}$, and aldicarb $10 \mathrm{G}$ were each applied at planting in three single doses $(32.04,64.08$ and $96.12 \mathrm{~kg} / \mathrm{ha})$, and both at planting as well as 4 months later in three split doses $(16.02+16.02,32.04+32.04$, and $48.06+48.06$ $\mathrm{kg} / \mathrm{ha}$ ). Treatments were replicated four times and arranged in a partially balanced incomplete block design. In 1980, carbofuran 10G $(6.7,13.4$, $29.9 \mathrm{~kg} / \mathrm{ha}$ ); fensulfothion $15 \mathrm{Gr}(5.2,10.5,21.1 \mathrm{~kg} / \mathrm{ha})$ and aldicarb $10 \mathrm{G}$ $(13.4,26.9,53.8 \mathrm{~kg} / \mathrm{ha}$ ) were replicated four times and arranged in a partially balanced incomplete block design. In 1981, carbofuran $10 \mathrm{G}$ and aldicarb $10 \mathrm{G}(13.4,26.9,53.8 \mathrm{~kg} / \mathrm{ha})$ were replicated four times, but this time arranged in a balanced incomplete block design. 


\section{RESULTS AND DISCUSSION}

Tables 1 to 3 show the results of the three experiments. Table 1 presents the results of 1979 . The statistical analysis reveals that there were no significant differences between single and split treatments of the same nematicide. Significant increases in yields of high quality yams were obtained only when fensulfothion was applied in two applications of $32.04 \mathrm{~kg} / \mathrm{ha}$ each, and with all aldicarb treatments.

Table 2 shows the results of the 1980 experiment. Significant increases in yields of high quality yams were obtained with the treatments of 13.4 $\mathrm{kg} / \mathrm{ha}$ of carbofuran and aldicarb and with $53.8 \mathrm{~kg} / \mathrm{ha}$ of aldicarb. In this experiment both yield and nematode control were low. There is no

TABLE 1.-Average production of high quality yams (Dioscorea rotundata) and percent control of nematodes in soil after nematicide treatment (1979)

\begin{tabular}{llcc}
\hline \multicolumn{1}{c}{ Treatment } & & Yield & $\begin{array}{c}\text { Nematode } \\
\text { control }^{1}\end{array}$ \\
\hline Cag/ha & & $t / h a$ & $\%$ \\
Carbofuran 5G, & 32.04 & 8.9 & 36 \\
Carbofuran 5G, & $16.02+16.02$ & 9.1 & 61 \\
Carbofuran 5G, & 64.08 & 7.7 & 63 \\
Carbofuran 5G, & $32.04+32.04$ & 11.6 & 50 \\
Carbofuran 5G, & 96.12 & 7.2 & 46 \\
Carbofuran 10G, & $48.06+48.06$ & 9.5 & 60 \\
Carbofuran 10G, & 32.04 & 7.4 & 51 \\
Carbofuran 10G, & $16.02+16.02$ & 12.5 & 62 \\
Carbofuran 10G, & 64.08 & 9.3 & 52 \\
Carbofuran 10G, & $32.04+32.04$ & 5.1 & 60 \\
Carbofuran 10G, & 96.12 & 9.2 & 53 \\
Fensulfothion 15G, & $48.06+48.06$ & 8.5 & 57 \\
Fensulfothion 15G, & 32.04 & 6.0 & 45 \\
Fensulfothion 15G, & $16.02+16.02$ & 6.9 & 56 \\
Fensulfothion 15G, & 64.08 & 6.8 & 75 \\
Fensulfothion 15G, & $32.04+32.04$ & $15.4^{* 2}$ & 66 \\
Fensulfothion 15G, & 96.12 & 12.9 & 68 \\
Aldicarb 10G, & $48.06+48.06$ & 10.1 & 50 \\
Aldicarb 10G, & 32.04 & $14.0^{*}$ & 80 \\
Aldicarb 10G, & $16.02+16.02$ & $23.3^{* * 3}$ & 76 \\
Aldicarb 10G, & 64.08 & $19.5^{* *}$ & 63 \\
Aldicarb 10G, & $32.04+32.04$ & $17.2^{*}$ & 91 \\
Aldicarb 10G, & 96.12 & $20.4^{* *}$ & 84 \\
Control & $48.06+48.06$ & $16.7^{* * *}$ & 86 \\
\hline I Bat & - & 4.2 & - \\
\hline
\end{tabular}

${ }^{1}$ Based on an average of three $250 \mathrm{~cm}^{3}$ soil samples composed mainly of $P$. coffeae and Rotylenchulus.

${ }^{2}$ Significant difference (5\%) over control.

${ }^{3}$ Significant difference (1\%) over control. 
experimental evidence to explain these findings, but the possibility that a low control of nematodes could be correlated with low production of high quality yams cannot be ruled out.

Table 3 presents the results of the 1981 experiment. Treatments of $53.8 \mathrm{~kg} / \mathrm{ha}$ with carbofuran and aldicarb signficantly increased the yields of high quality tubers over that of the control. Yield increases with

TABLE 2.-Average production of high quality yams (Dioscorea rotundata) and percent control of nematodes in soil after nematicide treatments (1980)

\begin{tabular}{crlc}
\hline Treatment & & Yield & $\begin{array}{c}\text { Nematode }_{\text {control }^{1}} \\
\text { Cag/ha }\end{array}$ \\
Carbofuran 10G, & 6.7 & \multicolumn{1}{c}{ t/ha } & $\%$ \\
Carbofuran 10G, & 13.4 & 1.9 & -36 \\
Carbofuran 10G, & 26.9 & $4.2^{*}$ & 15 \\
Fensulfothion 15G, & 5.2 & 2.5 & 10 \\
Fensulfothion 15G, & 10.5 & 1.6 & 14 \\
Fensulfothion 15G, & 21.1 & 2.8 & 23 \\
Aldicarb 10G, & 13.4 & $3.9^{* 2}$ & -64 \\
Aldicarb 10G, & 26.9 & 1.8 & 35 \\
Aldicarb 10G, & 53.8 & $3.6^{*}$ & 58 \\
Control & & 0.7 & 27 \\
\hline
\end{tabular}

${ }^{1}$ Based on an average of three $\mathrm{cm}^{3}$ soil samples composed mainly of $P$. coffeae and Rotylenchulus.

${ }^{2}$ Significant difference $(5 \%)$ over control.

TABLE 3.-Average production of high quality yams (Dioscorea rotundata) and percent control of nematodes in soil after nematicide treatment (1981)

\begin{tabular}{lccc}
\hline \multicolumn{1}{c}{ Treatment } & & Yield & $\begin{array}{c}\text { Nematode }_{\text {control }^{1}} \\
\text { kg/ha }\end{array}$ \\
Carbofuran 10G, & 13.4 & $t / h a$ & $\%$ \\
Carbofuran 10G, & 26.9 & 3.2 & 59 \\
Carbofuran 10G, & 53.8 & 1.8 & 31 \\
Aldicarb 10G, & 13.4 & $7.8^{* 2}$ & 43 \\
Aldicarb 10G, & 26.9 & $6.8^{*}$ & 65 \\
Aldicarb 10G, & 53.8 & $8.9^{*}$ & 62 \\
Control & & $13.7^{* * 3}$ & 72 \\
\hline
\end{tabular}

${ }^{1}$ Based on an average of three $250 \mathrm{~cm}^{3}$ soil samples composed mainly of $P$. coffeae and Rotylenchulus.

${ }^{2}$ Significant difference ( $5 \%$ ) over control.

${ }^{3}$ Significant difference (1\%) over control.

aldicarb were highly significant. Aldicarb also increased yields significantly when applied at 13.4 and $26.9 \mathrm{~kg} / \mathrm{ha}$. Nematode control in plots with higher yields was a significant $43 \%$ or higher. The highest nematode control $(72 \%)$ was obtained with aldicarb at $53.8 \mathrm{~kg} / \mathrm{ha}$, the treatment which yielded highest.

The data reported herein indicated that aldicarb was more effective in 
controlling nematodes and increasing yields of high quality tubers than carbofuran and fensulfothion. The results are in agreement with those found by other investigators $(3,4)$. The absence of significant differences between single and split applications of the same nematicide indicates that the data does not support the need for post-planting treatments. The results also indicate that the use of highly effective nonvolatile nematicides, if registered for their use in yam, could help in reducing the annual crop losses caused by nematodes, mainly P. coffeae, in Puerto Rico.

\section{RESUMEN}

Se hicieron tres experimentos de campo para evaluar el efecto de nematicidas no volátiles en ñame (Dioscorea rotundata Poir). Los nematicidas se aplicaron al sembrar, o al sembrar y después de la siembra. El aldicarb fue más eficaz que el carbofuran y el fensulfothion en el control de nematodos y aumento de tubérculos de alta calidad. No se encontró diferencia significativa entre los tratamientos en los que el nematicida se aplicó en una sola aplicación al sembrar y en los que la dosis se dividió para efectuar una segunda aplicación más tarde. Los resultados dejan por sentado la importancia de controlar los nematodos en la producción de ñames.

\section{LITERATURE CITED}

1. Abdel-Rahman, T. B., Elgindi, D. M., and Oteifa, B. A., 1974. Efficacy of certain systemic pesticides in the control of root-knot and reniform nematodes of potatoes, Plant Dis. Rep. 58: 517-20.

2. Acosta, N. and Ayala, A., 1975. Pathogenicity of Pratylenchus coffeae, Scutellonema bradys, Meloidogyne incognita, and Rotylenchulus reniformis on Dioscorea rotundata, J. Nematol. 7: 1-6.

3. Adesiyan, S. O. and Badra, T., 1982. Granular nematicides for control of the yam nematode, Scutellonema bradys, and relevant residues in raw tubers, J. Nematol. 14: 213-16.

4. Anonymous, 1980. Chemical and hot water therapeusis for yam control, Annual Report International Institute of Tropical Agriculture, Nigeria, p. 71-72.

5.—, 1981. Facts and Figures on Puerto Rico's Agriculture (1978-79 and 1979-80), Department of Agriculture, Commonwealth of P.R., p. 43.

6. Ayala, A. and Acosta, N., 1971. Observations on yam (Dioscorea alata) nematodes, Nematropica 1: 39-40.

7. Badra, T. and Caveness, F. E., 1979. Chemotherapy of Dioscorea alata for disinfection of Scutellonema bradys, Nematropica 9: 135-37.

8. - and Elgindi, D. M., 1979. Single and double combinations of nematicides against Rotylenchulus reniformis and Tylenchulus semipenetrans infecting cowpea and citrus, Rev. Nematol. 2: 23-7.

9. - Steele, W. W., and Caveness, F. E., 1980. The employment of a nonfumigant nematicide for control of the root-knot and lesion nematodes on yams and crop preservation in storage, Nematropica 10: 81-5.

10. Birchfield, W. and Martin, J. 1968. Evaluation of nematicides for controlling reniform nematodes on sweet potatoes, Plant Dis. Rep. 52: 127-31. 


\section{JOURNAL OF AGRICULTURE OF UNIVERSITY OF PUERTO RICO}

11. Christie, J. R. and Perry, V. G., 1951. Removing nematodes from soil, Proc. Helminthol. Soc. Wash. 18: 106-08.

12. Coates-Beckford, Phyllis L., 1977. Comparison of various treatments for the control of Pratylenchus coffeae in yam, Nematropica 7: 20-6.

13. Greco, N. and Lamberti, F., 1977. Further trials on the chemical control of Heterodera carotae in Puglia, Inform. Fitopatol. 27:15-8.

14. Griffin, C. D., 1975. Control of Heterodera schachtii with foliar applications of nematicides, J. Nematol. 7: 347-51.

15. Mackintosh, G. M., Osborne, P., Stewart, R. N. and Trudgill, D. L., 1977. Control of potato cyst eelworm with a resistant cultivar and with nematicides in Scotland, Proc. Symp. on Problems of Pest and Disease Control in Northern Britain, Mar. 23-24, Dundee, Scotland: $36-37$.

16. Román, J., Oramas, D. and Green, J., 1980. Investigations on the control of yam (Dioscorea rotundata) nematodes, Nematropica 10: 71-2.

17. Steel, A. E., 1976. Effects of oxime carbamate nematicides on development of Heterodera schachtii on sugar beet, J. Nematol. 8: 137-41.

18. Steiner, G., 1931, A nematosis of yams caused by a new species of Hoplolaimus, Plant Dis. Rep. 15:121.

19. West, J., 1934. Dry rot of yams, Bull. Imp. Int., London 32: 448-50. 